DOI 10.31558/2519-2949.2021.1.15

УДК 327-044.247(477: СС)

ORCID ID: https://orcid.org/0000-0002-2850-2059

Дудкевич В. І., Прикарпатський національний університет

імені Василя Стефаника

\title{
ПРОЦЕС ІНТЕГРАЦІЇ УКРАЇНИ ДО ЄВРОПЕЙСЬКОГО СОЮЗУ В КОНТЕКСТІ СУПЕРЕЧНОСТЕЙ ВНУТРІШНЬО ЄВРОПЕЙСЬКОГО РОЗВИТКУ
}

У статті досліджується проиес інтеграиії України до Європейського Союзу. Зокрема, обтрунтовуються зовнішньо зумовлені фактори, що впливають на ефективність євроінтеграційного процесу. Основними визначено геополітичні умови, стратегічні засади та внутрішньоєвропейські суперечності, що можуть нести загрозу розвиткові

Украӥни. Систематизовано наукові підходи до вивчення європейських інтеграчійних прочесів, з'ясовано геополітичні умови євроінтеграиії Украӥни та розкрито вплив суперечностей внутрішньоєвропейського розвитку на процес євроінтеграиії України.

Серед стратегічних засад здійснення інтеграиійного прочесу виділено зовнішній вимір, який полягає у налагодженні тісних політичних та економічних зв'язків з СС. Подальший розвиток відносин України та ЄС визначається підписанням Угоди про асоиіацію та ї̈ ратифікачія Верховною Радою України та Свропарламентом, а також т виконання Украйною означених вимог.

Визначено суперечності внутрішньоєвропейського розвитку, які можуть нести потенційну загрозу та створювати додаткові ризики для процесу інтеграції України. Сюди можна віднести критичне ставлення деяких країн-членів СС щодо спроможності Украӥни системно реформувати політичну й економічну системи, щоб вони відповідали європейським стандартам; існуючі в СС проблеми стосовно остаточної інтеграиії країн, які отримали членство у ХХІ ст. та послаблений консолідачійний потенціал краӥн-членів щуодо внутрішньої політики $Є C$.

Зроблено висновок, що інтенсивність та результативність євроінтеграційного процесу в Україні залежить найбільшою мірою від суб 'єктивних чинників, тобто позицї релевантного політичного лідера.

Ключові слова: інтеграчія Украӥни; Свропейський Союз; внутрішньо європейський розвиток; євроінтеграчійний прочес; геополітичні умови євроінтеграчії України

Постановка проблеми та її зв'язок із важливими науковими та практичними завданнями Актуальність дослідження зумовлена складною політичною, соціально-економічною ситуацією в контексті проблем, що виникли в процесі європейської інтеграції. Потреба науково-теоретичної розробки сутності та змісту інтеграційних процесів сучасного світу, суперечливий і непослідовний характер вироблення та втілення європейської парадигми української геополітики зумовили важливість нашого наукового дослідження.

Метою дослідження $\epsilon$ науково-теоретичне обгрунтування зовнішньо зумовлених факторів, що впливають на ефективність євроінтеграційного процесу, основними 3 яких визначено геополітичні умови, стратегічні засади та внутрішньо європейські суперечності, що можуть нести загрозу розвиткові України

3 огляду на поставлену мету визначено дослідницьке завдання - систематизувати наукові підходи до вивчення європейських інтеграційних процесів; з'ясувати геополітичні умови євроінтеграції України; розкрити вплив суперечностей внутрішньоєвропейського розвитку на процес євроінтеграції України.

Аналіз останніх досліджень і публікацій, в яких започатковано розв'язання даної проблеми

Необхідно зазначити, що європейська інтеграція в сучасному розумінні - це явище XX ст. У цей період такі науковці, як Ж. Монне, П.-А. Спаак, К. Аденауєр зазначали, що для європейців «європеїзм» $є$ найконструктивнішою ідеєю століття, а логіка потребує від них об'єднання зусиль, досвіду, енергії, навичок у спільних інтересах [6, с. 10]. А загальним доктринальним підгрунтям 
наукового пошуку стали праці вітчизняних учених: Барабаша Ю.Г., Батанова О.В., Білої-Тіунової Л.Р., Бориславської О.М., Крестовської Н.М, Коваля В.С., Колісника В.П., Крусян А.Р., Марцеляка О.В., Мяловицької Н.А., Оборотова Ю.М., Орзіха М.П., Рабіновича П.М., Скрипнюка О.В., Совгирі О.В., Стецюка П.Б., Федоренка В.Л., Фрицького Ю.О., Шемшученка Ю.С., Юзькова Л.П. та ін.

Виклад основного матеріалу дослідження. Вигідне географічне положення (Україна знаходиться в Центрально-Східній Європі на перехресті важливих транспортних шляхів між державами і континентами, межує з багатьма країнами і має вихід до Чорного і Азовського морів, доступні гірські перевали Українських Карпат не створюють значних труднощів для різних сухопутних видів транспорту [2, с. 5]), з одного боку, дозволяє Україні мати економічні переваги від певного посередництва між країнами Західної, Центральної та Східної Європи та Російською Федерацією, а з іншого, спричиняє боротьбу релевантних геополітичних гравців (СС, США, РФ) за необхідний їм вектор української зовнішньої політики. А враховуючи масштаб розширення ЄС у XXI ст., яке призвело до того, що саме по Україні проходить кордон між Свросоюзом та Росією, відзначаємо надвисоку роль геополітичного чинника, який впливає не лише на розбудову зовнішньої, a і на внутрішню політику України.

Вище керівництво країни, розуміючи вигідне, проте однозначно складне геополітичне становище України, протягом усієї історії незалежності намагалося поводити витриману зовнішньополітичну лінію. Характеризуючи одним словом спрямування зовнішньої політики України, можна обрати термін «багатовекторність». Вигідність геополітичного становища України несе великі приховані ризики. Україну можна відносити до «буферної зони» між Російською Федерацією та Європейським Союзом, «спільного простору» зовнішньої безпеки для РФ та СС, яка протягом тривалого часу була внутрішньо поділена у своїй зовнішньополітичній орієнтації між Сходом і Заходом та спрямовувала свої зусилля щодо співробітництва в напрямі двох систем. Така геополітична невизначеність, на нашу думку, сприяла зовнішній та внутрішній політичній напруженості, що призвела до підвищення рівня конфліктності в країні.

Аналіз наукових досліджень цього питання дає змогу констатувати, що, незважаючи на заявлену (ще в Постанові Верховної Ради УРСР від 25 грудня 1990 р. «Про реалізацію Декларації про державний суверенітет України усфері зовнішніх зносин») європейську спрямованість зовнішньополітичного курсу Україну, перші реальні кроки в забезпеченні цього наміру були зроблені після Помаранчевої революції Президентом В. Ющенком.

Визнаючи потужний інтеграційний потенціал України, і ЄС, і РФ намагаються залишити ії у полі свого геополітичного впливу, пропонуючи певні переваги. Важливість утримання України в напрямку т. зв. «проросійського вектору» пояснюється такими чинниками:

- Україна є важливою складовою ідеї «російського світу», який являє собою ідеологічну основу євразійства. Тим більше, що одним із трьох «стовпів» його $є$ православ'я, коріння і міцна база якого $\epsilon$ в Україні;

- Україна забезпечує «імперськість» Російської Федерації, про що стверджують як російські, так і західні геополітики;

- Україна (через Київську Русь) забезпечує історичну спадковість державної влади в РФ;

- Україна забезпечить Росії переваги використання свого вигідного транзитного становища;

- Україна залишається більш вигідним економічним партнером, ніж, наприклад, країни Середньої Азії;

- i, що головне, Україна може забезпечити непотрібний авторитарній політичній системі РФ «перелив» демократії, який несе загрозу стабільності недемократичних політичних режимів пострадянських країн. Саме тому Російська Федерація намагається (використовуючи як легальні, так і такі, що суперечать нормам міжнародного права, методи) утримати Україну в полі свого геополітичного впливу..

Вважаємо, що саме європейський поступ забезпечить проведення системних реформ у всіх галузях суспільства, тому що без них перспектива вступу України до ЄС стане неможливою. Послідовний євроінтеграційний процес приведе до розбудови фактичного, а не формального демократичного політичного режиму, формування функціонально дієздатного громадянського суспільства, забезпечить внутрішньоконсолідовану політичну націю, дієву реалізацію прав і свобод громадян, модернізацію економічної системи тощо.

Говорячи про перспективи економічного співробітництва, відзначимо, що підписана з Україною Угода про асоціацію передбачає створення Зони вільної торгівлі на таких вигідних для України умовах, які ще не надавалися СС будь-якій іншій державі. Тим більше, що виконання економічних 
критеріїв вступу до СС уже сприятиме побудові сильної конкурентної економіки. Таким чином, абсолютні переваги (перш за все, докорінна трансформація політичної та економічної систем), які отримає Україна від європейського вектора розвитк очевидні.

Однак, саме стратегія характеризує засоби адаптації організації до свого зовнішнього середовища. Таким чином, ефективна реалізація курсу на інтеграцію з СС полягає в здійсненні системної адаптації до вимог, що висуваються Європейським Союзом до країн-кандидатів на членство. Проаналізувавши основні документи СС (Римський договір 1957 р., Маастрихтський договір 1992 р., Копенгагенську Декларацію Європейської Ради 1993 р., рішення Мадридського саміту Європейської Ради 1995 р.), ми виокремили п’ять груп вимог, відповідність яким забезпечує членство держави в СС: географічні критерії (країна-кандидат повинна географічно належати до Свропи); економічні критерії (ефективність функціонування національної ринкової економіки); політичні критерії (ЄС являє собою союз демократичних націй, де гарантуються права людини, виборність органів влади, демократична організація влади, децентралізація, конкурентність, дієвість громадянського суспільства тощо); критерій членства або інституційний, який включає 31 розділ acquis communautaire - «спільного доробку $€ С »$; «незалежний» критерій (спроможність Європейського Союзу абсорбувати нових членів).

Проведене дослідження дозволяє констатувати повну відповідність України лише географічному критерію, що, безумовно, не є досягненням політичного керівництва країни.

Зовнішнім виміром реалізації інтеграційної стратегії $є$ налагодження зовнішньополітичних зв'язків між Україною та ЄС, а також формування відповідної законодавчої бази для підтримки цих відносин. Виділяємо п’ять етапів у розвитку цього процесу: 1) 1991-1994 рр. - утвердження принципу «багатовекторності» як засадничого для зовнішньополітичного курсу країни; 2) 1994-2004 pp. - реальне впровадження багатовекторності в зовнішній політиці при формальному декларуванні Європейської інтеграції України як стратегічної мети розвитку; 3) 2005-2010 pp.із перемогою В. Ющенка в президентських виборах 2004-2005pp. відбулася часткова зміна політичної та управлінської еліти країни із рекрутуванням на керівні посади проєвропейських лідерів. Відбулися фактична зміна державної зовнішньої політики України, початок реального впровадження курсу реформ, спрямованих на членство України в $Є С$, на тлі задекларованої у 2004 році програми «східного» розширення Європейського Союзу; 4) 2010-2013 pp. - охоплює період від проголошення підтримки Президентом В. Януковичем євроінтеграційної стратегії розвитку країни, початку парафування Угоди про асоціацію до раптової відмови уряду М. Азарова продовжувати підготовку до підписання Угоди на Саміті Східного партнерства у Вільнюсі; 5) 2014 р. - дотепер - унаслідок масових акцій протесту, однією з вимог яких було відновлення європейського поступу України, часткове переформатування складу політичної та управлінської еліти в результаті президентських виборів і кадрових перестановок, відбулося підписання Угоди про асоціацію та іiі ратифікація Верховною Радою України та Європейським Парламентом. Подальший розвиток відносин України та ЄС визначається цією Угодою та ефективністю виконання Україною означених вище вимог. Отже, можна зробити висновок, що інтенсивність і результативність євроінтеграційного процесу в Україні залежать найбільшою мірою від суб'єктивних чинників, тобто позиції релевантного політичного лідера.

Також необхідно визначити суперечності внутрішньоєвропейського розвитку, які можуть нести потенційну загрозу та створювати додаткові ризики для процесу інтеграції України. Сюди можна віднести:

- критичне ставлення деяких країн-членів ЄС щодо спроможності України системно реформувати політичну й економічну системи, щоб вони відповідали європейським стандартам;

- існуючі в СС проблеми стосовно остаточної інтеграції країн, які отримали членство у XXI ст.;

- послаблений консолідаційний потенціал країн-членів щодо внутрішньої політики СС;

- проблеми економічного розвитку СС, який демонструє останніми роками падіння темпів приросту ВВП;

- підвищення впливовості в Свропарламенті групи т. зв. «євроскептиків», які виступають за звуження повноважень наднаціональних органів $С$, аж до розпаду останнього [8,c.20].

Проте історія існування ЄС доводить його спроможність вирішувати подібні кризові явища, а перемогу скептично налаштованих до існування $\mathrm{CC}$ політичних партій ми відносимо до своєрідної оцінки за провальну діяльність національних урядів. Усі члени $\mathrm{CC}-$ це держави з високим рівнем демократії, захисту прав i свобод людини, прозорою системою відносин між владою та громадянином. Тож, незважаючи на кризові моменти, рівень життя і соціального захисту навіть у так 
званих «бідних» країнах ЄС залишається вищим, ніж в Україні, що виступає додатковим стимулом у дотриманні євроінтеграційного курсу.

Демократизація є основною умовою успішної євроінтеграції, прискорити яку спроможні інститути громадянського суспільства. Для аналізу процесу демократизації в Україні були залучені критерії демократичного політичного режиму, запропоновані Р. Скідельскі (виборність влади; свобода слова, зібрань, вільні 3МI; демократичний характер політичного лідерства; конституційне обмеження демократії; максимальна децентралізація влади), а також дані рейтингів міжнародної правозахисної організації Freedom House.

За всіма показниками констатуємо формальний підхід з боку політичних акторів до конституювання основ демократичного політичного режиму. Відзначаємо падіння явки виборців і тотальне зниження рівня довіри громадян до основних політичних інститутів, уповільнені темпи ротації органів влади. За наявності значної кількості засобів масової інформації їхня діяльність характеризується заангажованістю, тенденційністю, великою кількістю «замовних» матеріалів, які спотворюють дійсність, а також політичною цензурою. Доволі поширеними $є$ випадки тиску на журналістів, перешкоджання їхній професійній діяльності - аж до фізичного впливу. Все це дає змогу організації Freedom House віднести Україну до категорії країн із частково обмеженою свободою ЗМІ. При цьому в мережевому просторі Україна визначається умовно вільною країною. Говорячи про розвиток і впливовість ЗМI, необхідно наголосити, що вони мають значний рейтинг довіри від громадян, набагато вищий, ніж до політичних інститутів. Тому демократизація ЗМІ однозначно сприятиме підвищенню якості демократії. Аналізуючи роль лідерства у формуванні української демократії, стверджуємо про абсолютну персоніфікацію політичного процесу в Україні. Дані соціологічних досліджень демонструють готовність громадян віддавати свої голоси за лідера, а не організацію (що, у свою чергу, приводить до формування та існування в країні виключно лідерських політичних партій). При цьому існує суспільний запит на політичного лідера нового типу, який відзначатиметься такими якостями, як чесність, некорумпованість і готовність захищати інтереси простих людей. Стосовно конституційного обмеження влади, то воно повинно забезпечуватися ефективною судовою системою.

Істотно знижує можливість подолання проблем внутрішніх суперечностей між країнами-членами можливі прийнятні варіанти їхнього вирішення. Основними опонентами виступають Франція та Німеччина. Якщо Франція виступає за обмеження впливу ЄС на національні уряди з метою максимального збереження суверенітету (при цьому пропонується ідея «комунізації європейського боргу»), то Німеччина пропонує посилити внутрішньополітичні зв'язки (мова йде про необхідність реформування по суті конфедеративного устрою $С С$ уфедеративний) та зауважує, що без наднаціонального контролю над національними бюджетами політика «комунізації європейського боргу» є нездійсненною.

Проте історія існування та здобутки СС демонструють високу економічну та політичну ефективність даного інтеграційного об'єднання. Усі члени $\mathrm{CC}-$ це держави з високим рівнем демократії, захисту прав та свобод людини, прозорою системою відносин між владою та громадянином [4], [5].

Зрозуміло, що для просування інтересів України на рівні ЄС нашій державі потрібне потужне проукраїнське лобі в політичних і бізнесових колах ЄС. Найбільш активною $є$ підтримка Польщі, яка $\epsilon$ найбільшим українським патроном в євроінтеграційних справах, «адвокатом України» у Європі, держав Балтії (особливо Литви), можливо Чехії, Словаччини, Угорщини, Румунії, Болгарії, а також Швеції та Данії, які, зокрема, неодноразово заявляли про свою підтримку євроінтеграційних прагнень України.

Однак, необхідно констатувати, що наразі в України немає злагоджених механізмів ефективного представлення та відстоювання своїх національних інтересів у Свросоюзі. При цьому найпотужніші держави СС - Франція та Німеччина, незважаючи на відсутність єдності між ними щодо низки аспектів інтеграції, обидві недвозначно виступають проти надання Україні європейських перспектив. Тому сьогодні відчутною $є$ потреба пошуку прихильників України всередині самого інтеграційного утворення та лобіювання поширення такого підходу до єдиної Європи, який включатиме й Україну [3].

Висновки. Інтеграційний потенціал держави формується під впливом зовнішніх та внутрішніх чинників, що склалися в країні. Геополітичні умови євроінтеграції зумовлюються вигідним географічним положенням України. 3 моменту отримання незалежності зовнішньополітичний курс держави визначався парадигмою багатовекторності, яка почала трансформуватися у європейську 
лише після подій «Помаранчевої революції» та перебування на посаді Президента В. Ющенка. Така геополітична невизначеність призвела до перетворення України на зону потенційної конфліктності та боротьби за переважний вплив не неї з боку найбільш релевантних геополітичних суб'єктів. Зараз СС визначає свої відносини з Україною через реалізацію Ініціативи «Східного партнерства», яка спрямована на укладання Угоди про асоціацію і поглиблену та всеосяжну зону вільної торгівлі, секторальну інтеграцію до європейського ринку, лібералізацію візового режиму, поширення формату регіональної інтеграції та взаємодії на рівні громадянського суспільства.

Досліджуючи зовнішні чинники, які впливають на процес євроінтеграції України, необхідно також враховувати внутрішньоєвропейські суперечності, що можуть нести певні ризики для соціально-економічного розвитку України. До останніх можна віднести послаблення консолідаційного потенціалу країн-членів щодо внутрішньої політики $Є С$; необхідність завершення ряду системних реформ, необхідність яких зумовлена останнім розширенням СС; економічні проблеми, що виникли внаслідок неоднорідного економічного розвитку окремих регіонів.

\section{Бібліографічний список:}

1. Байков А. А. «Мягкая мощь» Европейского Союза в глобальном силовом равновесии: евро-российский трек. Вестник МГИМО-Университета. 2018. № 2. С. 36-46.

2. Заремба О. В. Геополітичні ідеї та гіпотези в українській політичній думці XX - початку XXI століття. / Заремба О. В., Федоренко О. А. К. : «Золотые ворота», 2019. 209 с.

3. Лях М. Роль внутрішніх і зовнішніх чинників у процесі європейської інтеграції Польщі: уроки для України. Науковий блог НаУ «Острозька Академія». 24.05.2012. URL: http://naub.oa.edu.ua/2012/rolvnutrishnih-i-zovnishnih-chynnykiv-u-protsesi-jevropejskoji-intehratsiji-polschi-uroky-dlya-ukrajiny/

4. Нагорна Л. П. Соціокультурна ідентичність: пастки ціннісних розмежувань. К. : ІПіЕНД ім. І. Ф. Кураса НАН України, 2011. 272 с.

5. Report for Selected Countries and Subjects Official website of The International Monetary Fund. URL : http://www.imf.org

6. Расширение ЕС на Восток: предпосылки, проблемы, последствия / [Под ред. Арбатовой Н. К., Гутника В. П., Хесина С. Е., Юданова Ю. И.]. М. : Наука, 2003. 344 с.

7. Східне партнерство Урядовий портал. URL: http://www.kmu.gov.ua/control/uk/publish/article\%3Fart_id=224168250\&cat_id=223345569

8. Тиркус Ю. С. Особливості стратегії інтеграції України до Європейського Союзу. Політологічні записки : зб. наук. пр. / [голов. ред. Г.П. Щедрова]. Луганськ : Вид-во СНУ ім. В. Даля, 2014. Вип. 1 (9). C. 319-327.

\section{References:}

1. Bajkov A. A. «Myagkaya moshh'» Evropejskogo Soyuza v global'nom silovom ravnovesii: evro-rossijskij trek Vestnik MGIMO-Universiteta. 2018. № 2. C. 36-46.

2. Zaremba O. V. Heopolitychni idei ta hipotezy v ukrainskii politychnii dumtsi KhKh - pochatku KhKhI stolittia. / Zaremba O. V., Fedorenko O. A. K. : «Zolotie vorota», 2019. 209 s.

3. Liakh M. Rol vnutrishnikh i zovnishnikh chynnykiv u protsesi yevropeiskoi intehratsii Polshchi: uroky dlia Ukrainy Naukovyi blog NaU «Ostrozka Akademiia». 24.05.2012. URL: http://naub.oa.edu.ua/2012/rol-vnutrishnih-izovnishnih-chynnykiv-u-protsesi-jevropejskoji-intehratsiji-polschi-uroky-dlya-ukrajiny/

4. Nahorna L. P. Sotsiokulturna identychnist: pastky tsinnisnykh rozmezhuvan / L. P. Nahorna. - K. : IPiEND im. I. F. Kurasa NAN Ukrainy, 2011. -272 c.

5. Report for Selected Countries and Subjects [Electronic resource] // Official website of The International Monetary Fund. - Mode of access : http://www.imf.org

6. Rasshirenie ES na Vostok: predposylki, problemy, posledstviya / [Pod red. Arbatovoj N. K., Gutnika V. P., Xesina S. E., Yudanova Yu. I.]. - M. : Nauka, 2003. - 344 c.

7. Skhidne partnerstvo [Elektronnyi resurs] // Uriadovyi portal. - Access mode : http://www.kmu.gov.ua/control/uk/publish/article\%3Fart_id=224168250\&cat_id=223345569

8. Tyrkus Yu. S. Osoblyvosti stratehii intehratsii Ukrainy do Yevropeiskoho Soiuzu / Yu. S. Tyrkus // Politolohichni zapysky : zb. nauk. pr. / [holov. red. H.P. Shchedrova]. - Luhansk : Vyd-vo SNU im. V. Dalia, 2014. - Vyp. 1 (9). C. 319-327.

\section{Dudkevych V. I. The Process of Ukraine's Integration into the European Union in the Context of the Contradictions of Internal European Development}

The article examines the process of Ukraine 's integration into the European Union. In particular, externally conditioned factors influencing the efficiency of the European integration process are substantiated. The main ones are geopolitical conditions, strategic principles and internal European contradictions that may threaten the development of Ukraine. The scientific approaches to the study of European integration processes are systematized, the geopolitical conditions of Ukraine's European 
integration are clarified and the influence of the contradictions of internal European development on the process of Ukraine's European integration is revealed. Among the strategic principles of the integration process is the external dimension, which means the establishment of close political and economic connections with the EU. The further development of relations between Ukraine and the EU is determined by the signing of the Association Agreement and its ratification by the Verkhovna Rada of Ukraine and the European Parliament, as well as the implementation of these requirements by Ukraine.

Contradictions of intra-European development have been identified, which may pose a potential threat and create additional risks for the process of Ukraine's integration. These include criticism from some EU member states of Ukraine's ability to systematically reform its political and economic systems to reach European standards; existing problems in the EU regarding the final integration of countries that have gained membership in the XXI century. and the weakened consolidation capacity of member states in EU domestic policy.

It is concluded that the intensity and effectiveness of the European integration process in Ukraine depends largely on subjective factors, namely the position of the relevant political leader.

Keywords: integration of Ukraine; European Union; intra-European development; European integration process; geopolitical conditions of Ukraine's European integration 